\title{
Tuber wild plants of Shinasha people as food and medicine in Bullen district, North West of Ethiopia
}

\begin{abstract}
Bullen district is noted for its rich diversity of plant species apart from wetlands to flood plains serving the habitat requirement of several inhabitant communities and is unique in its nature by having rich diversity of wild edible plants. A number of cultivated tuber food plants such as Qocho (Dioscorea cayenensis), Anchote (Coccinia abyssinica), Sekuar Dinich (Ipomoea batatas, Dinich (Plectranthus edulis), Zingibil (Zingiberof ficiaale) and Godere (Colocasia esculanta) etc. having their wild relatives such as Colocasia esculenta, Curcuma bulbifera, Dioscorea prehensilis, Dioscorea hispida and Dioscorea oppositifolia etc. are present in the district. The present survey encompasses documentation previous of 29 wild tuberous plant species belonging to 15 family and 24 genera tabulated with botanical name, local name, and family, habit and habitat mode of consumption and medicinal uses.
\end{abstract}

Volume 2 Issue I - 2018

\author{
Mosissa D,' Abraha B² \\ 'Ethiopian Biodiversity Institute, Ethiopia \\ ${ }^{2}$ Department of Biology, Bahir Dar University, Ethiopia
}

Correspondence: Dereje Mosissa, Ethiopian Biodiversity Institute, Assosa Center Forest and Rangeland biodiversity case team, Assosa, Ethiopia, Tel +251949045964, Fax +25 I I I66 I 3722, Email derament5964@gmail.com

Received: December 05, 2017 | Published: January 31, 2018

Keywords: bullen, diversity, tuber, wild edible

\section{Introduction}

Plants provide food and medicine besides protecting the environment and are very important for survival of peoples. Human beings have adapted to the present life style of crop cultivation for food from hunting gathered nearly 10,000 years ago, probably due to population explosive, climate change, over hunting may be as simple disserve for more food. ${ }^{1}$ Wild edible plants are important in the livelihood strategies of local people, and forest dwellers in many developing countries. ${ }^{2}$ Western region of Ethiopia is rich in the floral diversity of roots and tubers. It harbours one of the richest biodiversity hot spots in the Western Ghats and the North eastern regions. The hotspot contains a large number of wild relatives of cultivated tuber crops as well as many under- exploited tuber crops known to tribals. Major portion of the genetic diversity of wild species and land races existing in the tropical forests and remote villages are yet to be explored, collected and conserved. ${ }^{3}$

Wild edible plants as alternative to staple food during deficit are valuable supplements for a nutritionally balanced diet. ${ }^{4}$ The wild tuber plants characteristically have a storage organ may be as true bulb, corm, tuber, tuberous root and rhizome. Carbohydrates and nutrients reserve are stored in these organs to support growth of plants. Nutritional profile of many wild edible plants have found comparable and sometime better to many cultivated varieties. ${ }^{5}$ Wild plants provide the medicines cheaply and readily available to the vast majority of the rural population, as is the case in many other developing countries in the world. They are also a source of some of the active ingredients in modern pharmaceuticals. However, the active compounds, proper methods of preparation, dosages, effectiveness and side effects of medicines prepared from these plants have not yet been studied extensively. ${ }^{6}$

The rural communities of developing countries depend on wild edible plants to meet their food requirements during periods of food shortage. Studies conducted by ${ }^{7}$ indicated that the wild edible plants are mostly serving as supplementary foods in different parts of Ethiopia. Wild edible plants are nutritionally rich $^{8}$ and can supplement especially vitamins and micronutrients. ${ }^{7}$ These show that wild edible plants are essential components of many African diets, especially in period of seasonal food shortage.

The Ethiopian flora has approximately 6000 species of higher plants of which about $10 \%$ are endemic. ${ }^{9,10}$ The country is known as the biodiversity hotspot and center of origin and diversification for a significant number of food plants and their wild relatives. ${ }^{11}$ The wide range of climatic and edaphic conditions permitted the growing of a variety of wild food plants. ${ }^{12}$ Some studies in Ethiopia indicated that many rural people are endowed with deep knowledge on how to use plant resources. This is particularly true with regard to the use of medicinal plants ${ }^{13}$ and wild edible plants that are consumed at times of famine and other hardships. ${ }^{7}$ In this regard, the elder community members are mostly the key sources of knowledge about plants. ${ }^{7}$

The consumption of wild plants seems more common in food insecure areas of the country as compared to relatively food sufficient areas. ${ }^{14}$ Although many rural people of Ethiopia usually feed on wild food tuber plants for survival during drought they also play an important role in securing the health of both people and live stocks. The available published studies on the diversity and ethnobotany of wild food plants especially of tubers are limited to specific area. ${ }^{10}$ In northwestern and western Ethiopia, the consumption of wild food plants seems to be one of the important local survival strategies and appears to have intensified due to the repeated climatic shocks hampering agricultural production and leading to food shortages. ${ }^{8}$ The Shinasha (Boro) people are one of the minority ethnic groups in Ethiopia. According to Ethiopian central statistics their population is estimated to be around 32,701. Their language Shinasha belongs to the North Omotic, Gonga language sub-family with Anfillo, Kafa and Sheka language and is spoken from the stretches of northwest to southwest Ethiopia.

The people live mostly in Metekel zone that is located about $650 \mathrm{~km}$ northwest of Addis Ababa the Ethiopian capital city. Their livelihood is based on subsistent agriculture (ploughing land and rearing animals for domestic use). The Shinasha people are known for their use of traditional medicine uniquely from geophytes and foods of wild sources than from many other Ethiopian ethnic groups. 
However, ethno botanically these people remain unexplored and no comprehensive account of their traditional practice is available. As is the case elsewhere in the country, both the traditional knowledge and the plants utilized by these people are under threat due to reasons mainly attributed to degradation, deforestation and overharvesting of rare species. This calls for an urgent action to collect and document the indigenous knowledge.

In Bullen Woreda of Benshanguel-Gumez region, the noncultivated plants provide considerable amount of supplementary food and have significant contribution to generating additional income for many households. However, there has not been sufficient research carried out about the indigenous knowledge of wild edible tuber plants in Bullen district. Therefore, this study was designed to identify and document wild edible tuber plant species, ${ }^{8}$ identify and record the parts and mode of consumption of wild edible tuber plants, ${ }^{7}$ evaluate the exploitation and conservation status of the species, and ${ }^{15}$ assess threats on the wild edible tuber plant species and recommend the possible management scenarios for their conservation.

\section{Materials and methods}

Ethno botanical survey with respect to wild edible tuberous plants was carried out during June 2015 to September 2016. The study area was frequently visited, local informants were used to locate and collect the plants. The uses of plants and its parts and method of usage were obtained through semi structured questionnaires, frequent interaction and discussion with local villagers, which included farmers, housewives and herdsmen. Live specimens and available photographs were shown to them for local identification. Standard methods were followed with regards to collection of plant materials, drying, mounting, preparation and preservation of herbarium sheets and museum sample. ${ }^{16}$ Botanical identification of the species were done with the help of floras of Ethiopia ${ }^{9}$ and also the herbarium collection maintained in AAU (Figure 1).

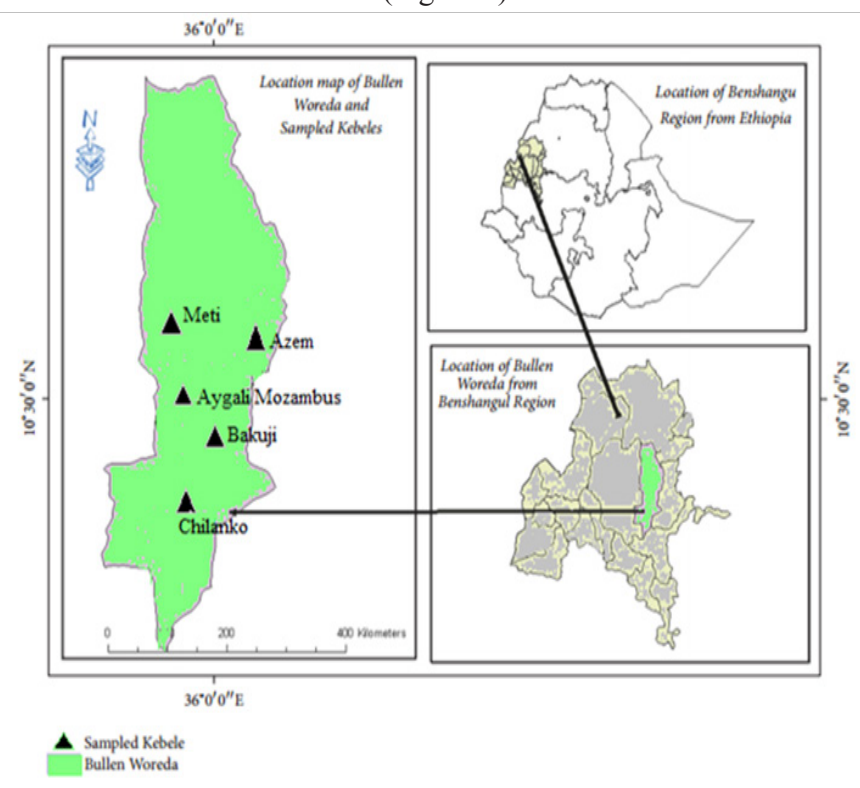

Figure I Location map of the study Woreda and sampled kebeles.

\section{Results and discussion}

The study provides empirical evidence about traditional knowledge and diversity of Wild tuberous plants. The study area is floristically rich and includes various useful wild tuberous plant species. The present survey encompasses the documentation of 29 wild tuberous plant species belonging to 15 family and 24 genera tabulated with botanical name, local name, and family, habit and habitat, mode of consumption and their medicinal uses. A maximum of 05 plants from Araceae, 05 from Dioscoreaceae, 03 from Liliaceae, 03 from Asclepiadaceae and 02 from Zingiberaceae 02 from Fabaceae and 01 from Passifloraceae, Aponogetonaceae, Costaceae, Hypoxidaceae, Commelinaceae, Cyperaceae, Euphorbiaceae, Nelumbonaceae, Alismataceae were reported along with photographs (Table $1 \&$ Figure 2 ). Wild tuberous plants have dual significance for their food value and some pharmaceutically active constituents. Most of the tuberous plants grow in shady and moist places due to habitat destruction and overexploitation for food and medicine. The wild tuberous plants are facing the threat of extinction e. g. Ceropegia, the fleshy underground parts of most of the species are eaten by animals apparently wild Warthog in the district and this probably accounts for the scarcity of these attractive plants. Therefore, proper and organized documentation of these plants and identification of potential species for prioritization of conservation through sustainable management is finding essential so that the resources and knowledge can be preserved, managed and utilized. The little emphasis made for the promotion of wild species were of significant importance to local farmers, recently there had been increased concern for the need to domesticate promising wild species as a long term source of income to the rural people.

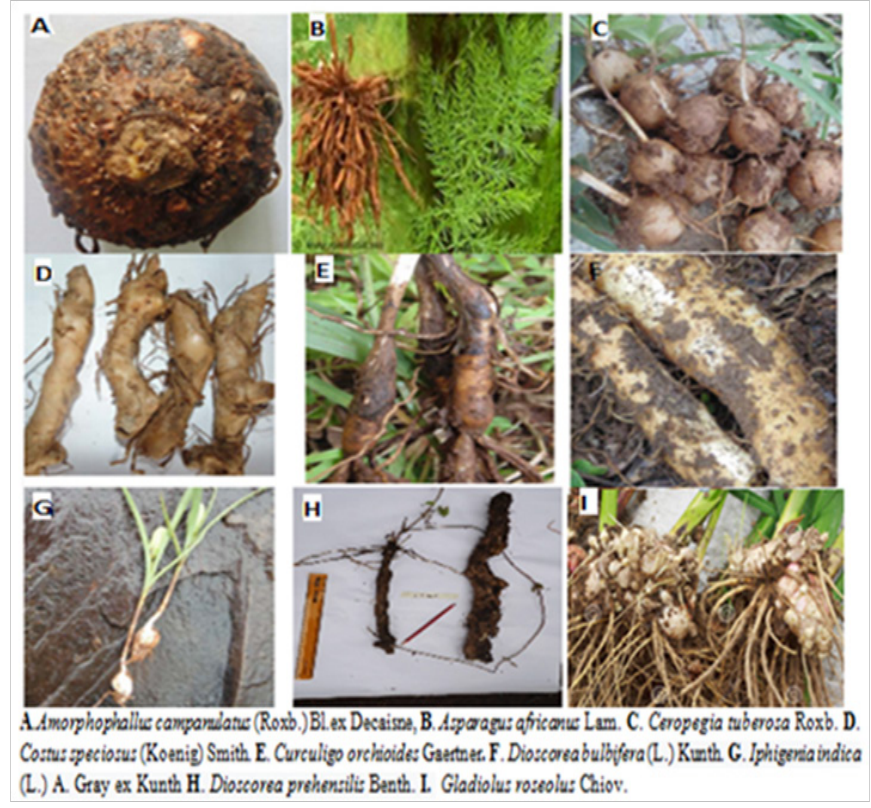

Figure 2 Some samples of wild food tubers collected in Bullen District.

\section{Conclusion}

The study on knowledge and diversity of tuberous wild plants with food and medicinal uses in Bullen District was immensely stated and documented. The study revealed that there are about 29 wild tuberous plant species belonging to 15 family and 24 genera of which all the household members of the study area collects and consumes for the purpose of medicine and as food resources. This helped to ensure the maintenance of indigenous knowledge associated with wild food plant species particularly of tubers. Many of the tuber plants found 
in the study area are found to be under growing pressure, due to anthropogenic and socioeconomic factors. This has resulted in the dwindling of the species of wild edible tuber plants and the associated indigenous knowledge of the people (Table 1). ${ }^{17-19}$

Table I List of wild tuber food and medicinal plants in Bullen District

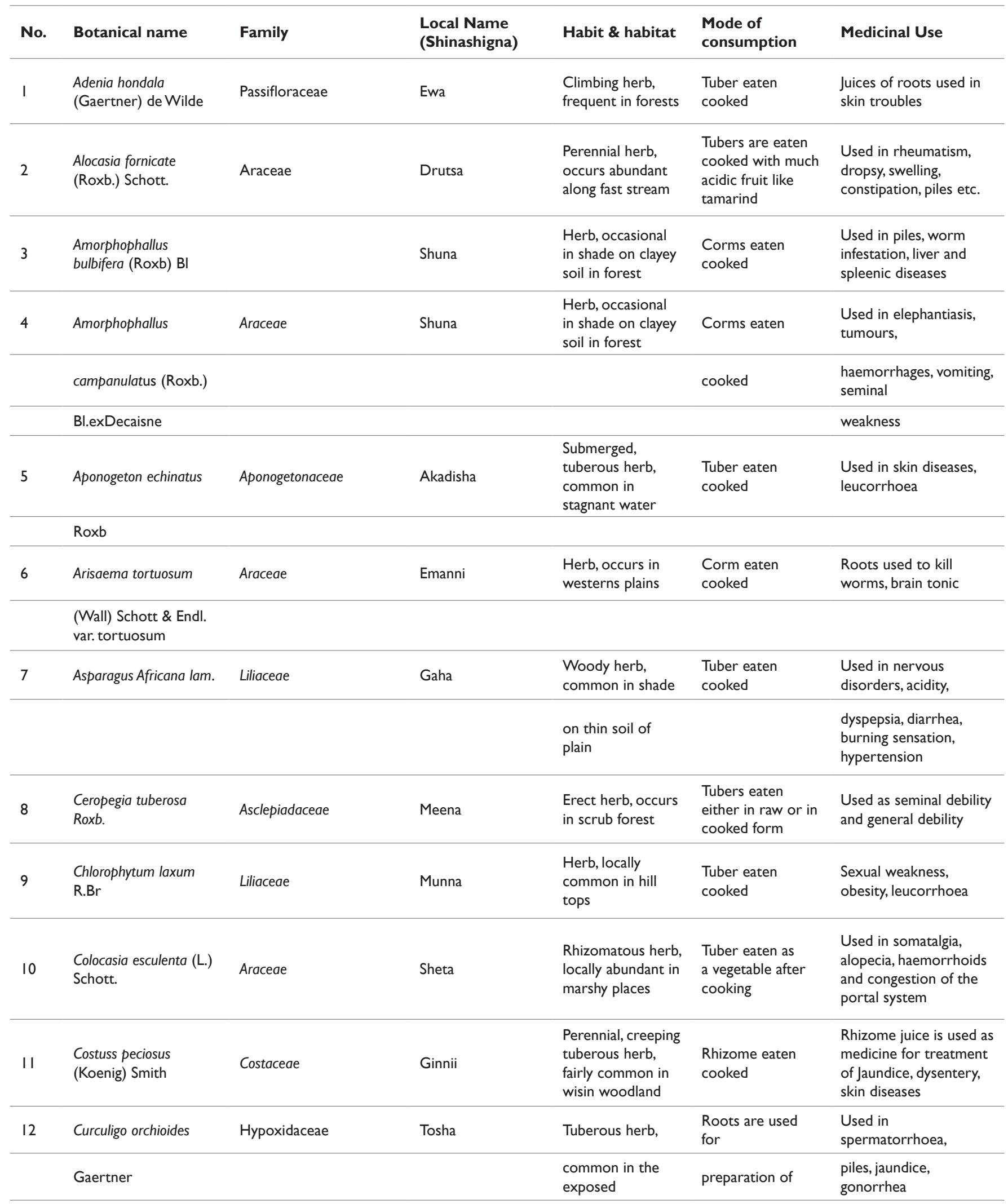


Table Continued.

\begin{tabular}{|c|c|c|c|c|c|c|}
\hline No. & Botanical name & Family & $\begin{array}{l}\text { Local Name } \\
\text { (Shinashigna) }\end{array}$ & Habit \& habitat & $\begin{array}{l}\text { Mode of } \\
\text { consumption }\end{array}$ & Medicinal Use \\
\hline & & & & grassland & Local drinks & \\
\hline 13 & $\begin{array}{l}\text { Curcuma neilgherrensis } \\
\text { Wight. }\end{array}$ & Zingiberaceae & Bodi-zanzibila & $\begin{array}{l}\text { Perennial herbs, } \\
\text { Common on } \\
\text { exposed areas and } \\
\text { on hill slopes in } \\
\text { Wisin woodland }\end{array}$ & $\begin{array}{l}\text { Rhizome used } \\
\text { to flavor cooked } \\
\text { food }\end{array}$ & $\begin{array}{l}\text { Cardiac diseases, } \\
\text { abdominal disorders }\end{array}$ \\
\hline 14 & $\begin{array}{l}\text { Cyanotis tuberosa } \\
\text { (Roxb) }\end{array}$ & Commelinaceae & Shukarie & $\begin{array}{l}\text { Creeping, } \\
\text { tuberous herb, } \\
\text { common in sandy } \\
\text { soil of plains }\end{array}$ & $\begin{array}{l}\text { Tuberous root } \\
\text { eaten cooked }\end{array}$ & $\begin{array}{l}\text { Used in inflammation, } \\
\text { skin diseases, } \\
\text { verminosis, vomiting }\end{array}$ \\
\hline 15 & Cyperus rotundus $\mathrm{L}$. & Cyperaceae & Bambiya & $\begin{array}{l}\text { Herb, in plains, } \\
\text { as weed of } \\
\text { cultivation }\end{array}$ & $\begin{array}{l}\text { Tuberous root } \\
\text { eaten cooked }\end{array}$ & $\begin{array}{l}\text { Used in stomach and } \\
\text { bowel complaints }\end{array}$ \\
\hline 16 & $\begin{array}{l}\text { Decalepis hamiltonii } \\
\text { Wight \& Arn. }\end{array}$ & Asclepiadaceae & Meenna & $\begin{array}{l}\text { Climbing herb, } \\
\text { found in rocky } \\
\text { places }\end{array}$ & $\begin{array}{l}\text { Roots made into } \\
\text { pickles }\end{array}$ & $\begin{array}{l}\text { Used in polyuria, } \\
\text { haemorrhage, jaundice }\end{array}$ \\
\hline 17 & Dioscorea bulbifera L. & Dioscoreaceae & Shawat- matakeya & $\begin{array}{l}\text { Perennial climbers, } \\
\text { wet deciduous } \\
\text { forest }\end{array}$ & $\begin{array}{l}\text { Tubers are cut in } \\
\text { to small pieces } \\
\text { and boiled in } \\
\text { water, water is } \\
\text { decanted, cooked } \\
\text { and used as food }\end{array}$ & $\begin{array}{l}\text { Paste of tuberous root } \\
\text { is applied on erysipplas, } \\
\text { swellings, syphills, etc }\end{array}$ \\
\hline 18 & Dioscorea prehensilis & Dioscoreaceae & Anga & $\begin{array}{l}\text { Perennial climbers, } \\
\text { common in forest }\end{array}$ & $\begin{array}{l}\text { Tubers are cut in } \\
\text { to small pieces } \\
\text { and boiled in } \\
\text { water, water is } \\
\text { decanted, cooked } \\
\text { and used as food }\end{array}$ & $\begin{array}{l}\text { Tuber powder form } \\
\text { applied to ulcer }\end{array}$ \\
\hline & Bent. & & & & & \\
\hline 19 & $\begin{array}{l}\text { Dioscorea hispida } \\
\text { Dennst }\end{array}$ & Dioscoreaceae & Shawat- Matakeya & $\begin{array}{l}\text { Perennial climbers, } \\
\text { occurs in wet } \\
\text { forest }\end{array}$ & $\begin{array}{l}\text { Tubers are cut in } \\
\text { to small pieces } \\
\text { and boiled in } \\
\text { water, water is } \\
\text { decanted, cooked } \\
\text { and used as food }\end{array}$ & $\begin{array}{l}\text { Used in piles and } \\
\text { dysentery }\end{array}$ \\
\hline 20 & Dioscorea oppositifolia L. & Dioscoreaceae & Angga & $\begin{array}{l}\text { Perennial climbers, } \\
\text { common in forest }\end{array}$ & $\begin{array}{l}\text { Tubers are cut in } \\
\text { to small pieces } \\
\text { and boiled in } \\
\text { water, water is } \\
\text { decanted, cooked } \\
\text { and used as food }\end{array}$ & $\begin{array}{l}\text { Tubers used as tonic } \\
\text { and in swellings }\end{array}$ \\
\hline \multirow[t]{2}{*}{21} & Dioscorea pentaphylla L. & Dioscoreaceae & Annga & $\begin{array}{l}\text { Perennial climbers, } \\
\text { wet }\end{array}$ & $\begin{array}{l}\text { Tubers are cut in } \\
\text { to small pieces } \\
\text { and boiled in } \\
\text { water, water is } \\
\text { decanted, cooked } \\
\text { and used as food }\end{array}$ & $\begin{array}{l}\text { Tubers used as tonic } \\
\text { and in swellings }\end{array}$ \\
\hline & & & & deciduous forest & & \\
\hline \multirow[t]{2}{*}{22} & $\begin{array}{l}\text { Hemidesmus indicus } \\
\text { (L.) R. Br. }\end{array}$ & Asclepiadaceae & Futsa & $\begin{array}{l}\text { Climbing herb, } \\
\text { common in }\end{array}$ & $\begin{array}{l}\text { Root powder is } \\
\text { used as an additive } \\
\text { in preparation of } \\
\text { tea \& coffee }\end{array}$ & $\begin{array}{l}\text { Used in burning } \\
\text { sensation, skin }\end{array}$ \\
\hline & & & & wettest places & & $\begin{array}{l}\text { diseases, asthama, fits, } \\
\text { dyspepsia, helminthiasis }\end{array}$ \\
\hline
\end{tabular}


Table Continued.

\begin{tabular}{|c|c|c|c|c|c|c|}
\hline No. & Botanical name & Family & $\begin{array}{l}\text { Local Name } \\
\text { (Shinashigna) }\end{array}$ & Habit \& habitat & $\begin{array}{l}\text { Mode of } \\
\text { consumption }\end{array}$ & Medicinal Use \\
\hline \multirow[t]{2}{*}{23} & Iphigenia indica (L.) A. & Liliaceae & Zaza & $\begin{array}{l}\text { Herb, fairly } \\
\text { common in }\end{array}$ & $\begin{array}{l}\text { Corm eaten } \\
\text { cooked }\end{array}$ & Corms used in colic \\
\hline & Gray ex Kunth & & & $\begin{array}{l}\text { shade on grassy } \\
\text { soil of hills }\end{array}$ & & \\
\hline \multirow[t]{2}{*}{24} & $\begin{array}{l}\text { Manihot esculenta } \\
\text { Crantz }\end{array}$ & Euphorbiaceae & Kazawari & $\begin{array}{l}\text { Small tree, occurs } \\
\text { in Wisin woodland } \\
\text { forest }\end{array}$ & $\begin{array}{l}\text { Tubers eaten } \\
\text { cooked }\end{array}$ & The juice of tubers to \\
\hline & & & & & & treat constipation \\
\hline \multirow[t]{2}{*}{25} & Nelumbo nucifera & Nelumbonaceae & Echeqa & $\begin{array}{l}\text { Aquatic, perennial, } \\
\text { stoloniferous } \\
\text { herb, Common in } \\
\text { open tank }\end{array}$ & $\begin{array}{l}\text { Roots eaten } \\
\text { cooked }\end{array}$ & $\begin{array}{l}\text { Used in pharygopathy, } \\
\text { dysentery, smallpox, } \\
\text { cough }\end{array}$ \\
\hline & Gaertner. & & & & & \\
\hline \multirow[t]{2}{*}{26} & $\begin{array}{l}\text { Pueraria tuberosa } \\
\text { (Roxb. ex Wild.) D.C. }\end{array}$ & Fabaceae & Qulqa & $\begin{array}{l}\text { Climber, stream } \\
\text { beds, dry tracts, } \\
\text { Hill forests and in } \\
\text { Waste lands }\end{array}$ & $\begin{array}{l}\text { The tuber is fleshy, } \\
\text { tastes liquory and } \\
\text { eaten cooked }\end{array}$ & $\begin{array}{l}\text { Powered roots is given } \\
\text { in sprue, }\end{array}$ \\
\hline & & & & & & $\begin{array}{l}\text { rheumatism, swellings, } \\
\text { prostrate problems }\end{array}$ \\
\hline 27 & Sagittaria sagitifolia L. & Alismataceae & Jingita & $\begin{array}{l}\text { Rooted, } \\
\text { scapigerous herb, } \\
\text { occurs in wetlands }\end{array}$ & $\begin{array}{l}\text { Roots eaten } \\
\text { cooked }\end{array}$ & $\begin{array}{l}\text { Used as discutient; also } \\
\text { given to arrest flow of } \\
\text { milk in nursing mothers }\end{array}$ \\
\hline 28 & Vigna vexillata (L.) Rich. & Fabeceae & KafiAtsa & $\begin{array}{l}\text { Climbing herb, } \\
\text { occurs in forest }\end{array}$ & $\begin{array}{l}\text { Tuberous roots } \\
\text { are eaten cooked }\end{array}$ & $\begin{array}{l}\text { Paste of tuberous root } \\
\text { is applied on swellings }\end{array}$ \\
\hline 29 & $\begin{array}{l}\text { Zingiber montanum } \\
\text { (Koenig) Link ex A }\end{array}$ & Zingerberaceae & Zanzibila & $\begin{array}{l}\text { Herb, Moist, sandy, } \\
\text { loose soil in shady } \\
\text { places }\end{array}$ & $\begin{array}{l}\text { Roots made into } \\
\text { pickles }\end{array}$ & $\begin{array}{l}\text { Used in cough, } \\
\text { stomachache, asthama } \\
\text { and also as a vermifuge }\end{array}$ \\
\hline
\end{tabular}

\section{Acknowledgements}

The authors are grateful to the informants and local communities of Bullen district for sharing their incredible accumulated knowledge of the wild edible tuber plants in the field. Without their contribution, this study would have been impossible. Authors are also thankful to Forest officials of Forest Department of Bullen district for the support and encouragement provided during documentation of wild edible tuberous plants.

\section{Conflict of interest}

None of the authors of this paper has a financial or personal relationship with other people or organizations that could inappropriately influence or bias the content of the paper. It is to specifically state that "No Competing interests are at stake and there is No Conflict of Interest" with other people or organizations that could inappropriately influence or bias the content of the paper.

\section{References}

1. Cohen MN. The food crisis in prehistory: overpopulation and the origins of agriculture. New Haven, USA; 1976. p. 341.

2. Johns T, Kokwaro JO. Food plants of the Luo of Siaya District, Kenya Economic botany. 1991;45(1):103-113.
3. Edison S, Velayudhan KC, Easwari Amma CS, et al. Tropical root and tubers in: plant genetic resources: Horticultural crops. In: Dhillon BS, Tyagi RK, editors. Narosa publishing house, New Delhi, India; 2005.

4. Shresth PM, Dhillion SS. Diversity and traditional knowledge concerning wild food species in a locally managed forest in Nepal. Agroforesty system. 2006;66(1):55-63.

5. Sundriyal M, Sundriyal RC. Wild edible plants of the Sikkim Himalaya: Nutritive values of selected species. Economic Botany. 2001;55(3):377-390.

6. Ruffo CK, Birnie A, Bo Teng. Edible Wild Plants of Tanzania. Regional Land Management Unit (RELMA), Nairobi, Kenya; 2002.

7. Getahun A. The role of wild plants in the native diet in Ethiopia. Agro-Ecosystems. 1974;1:45-56.

8. Tesfaye A. Plant diversity in western Ethiopia. Ecology, ethnobotany and conservation. Faculty of Mathematics and Natural Sciences. University of Osla, Norway; 2007.

9. Tewoldebirhan GE. Diversity of the Ethiopian flora. In: Engles JMM, Hawks JG, editors. Plant Genetic Resources of Ethiopia. Cambridge, UK; 1991. p. 75-81.

10. Zemede A. Conservation and use of traditional vegetables in Ethiopia. In: Guarino L, editor. Proceedings of the IPGRI International Workshop on Genetic Resources of Traditional Vegetables Africa. ICRAF-HQ, Nairobi, Kenya; 1995. p. 65. 
11. Tesfaye A. A study on the ecology and ethnobotany of noncultivated food plants and wild relatives of cultivated crops in Gambela Region. south western Ethiopia, Addis Ababa, Ethiopia; 1997.

12. Addis G, Urga K, Dikasso D. Ethnobotanical study of edible wild plants in some selected districts of Ethiopia. Human Ecology. 2005;33(1):83-118.

13. Abebe D, Ayehu A. Medicinal Plants and Enigmatic Health Practice of Northern Ethiopia. Monograph, Addis Ababa, Ethiopia; 1993.

14. Abbink J. Meen ritual, medicinal and other plants. A contribution to South-West Ethiopian ethnobotany. Journal of Ethiopian Studie. 1993;26(2):1-21.

15. Azene B, Ann B, Tengnas B. Useful trees and shrubs for Ethiopia identification, propagation and management for agricultural and pastoral Community. Nairobi Regional Land Management Unit (RELMA). Sida, Nirobi, Kenya; 1993. p. 474.
16. Jain SK, Rao RR. A hand book of field and herbarium methods. Today and tomorrow Printer and Publishers, New Delhi, India; 1967.

17. Mandu PM, Nagugi GW, Kabuye CHS. Traditional Food Plants of Kenya. National Museums of Kenya, Nairobi, Kenya; 1999.

18. Saldanha CJ, Nicolson DH. Flora of Hassan District, Karnataka, India. Amerind Publishing Co Pvt Ltd, New Delhi, India; 1978.

19. Shresth PM, Dhillion SS. Diversity and traditional knowledge concerning wild food species in a locally managed forest in Nepal. Agroforesty system. 2006;66(1):55-63. 